Article

\title{
Synthesis and Thermochromic Luminescence of Ag(I) Complexes Based on 4,6-Bis(diphenylphosphino)-Pyrimidine
}

\author{
Alexander V. Artem'ev *(D), Maria P. Davydova, Alexey S. Berezin and Denis G. Samsonenko $\mathbb{D}$ \\ Nikolaev Institute of Inorganic Chemistry, Siberian Branch of Russian Academy of Sciences, 3, \\ Acad. Lavrentiev Ave., 630090 Novosibirsk, Russia; m_davydova@mail.ru (M.P.D.); berezin@niic.nsc.ru (A.S.B.); \\ denis@niic.nsc.ru (D.G.S.) \\ * Correspondence: chemisufarm@yandex.ru
}

Received: 6 August 2020; Accepted: 24 August 2020; Published: 26 August 2020

check for updates

\begin{abstract}
Two Ag(I)-based metal-organic compounds have been synthesized exploiting 4,6-bis (diphenylphosphino)pyrimidine (L). The reaction of this ligand with $\mathrm{AgNO}_{3}$ and $\mathrm{AgBF}_{4}$ in acetonitrile produces dinuclear complex, $\left[\mathrm{Ag}_{2} \mathrm{~L}_{2}(\mathrm{MeCN})_{2}\left(\mathrm{NO}_{3}\right)_{2}\right](\mathbf{1})$ and $1 \mathrm{D}$ coordination polymer, $\left[\mathrm{Ag}_{2} \mathrm{~L}(\mathrm{MeCN})_{3}\right]_{n}\left(\mathrm{BF}_{4}\right)_{2 n}(2)$, respectively. In complex $\mathbf{1}, \mu_{2}-\mathrm{P}, \mathrm{P}^{\prime}$-bridging coordination pattern of the ligand $\mathrm{L}$ is observed, whereas its $\mu_{4}-\mathrm{P}, \mathrm{N}, \mathrm{N}^{\prime}, \mathrm{P}^{\prime}$-coordination mode appears in 2 . Both compounds exhibit pronounced thermochromic luminescence expressed by reversible changing of the emission chromaticity from a yellow at $300 \mathrm{~K}$ to an orange at $77 \mathrm{~K}$. At room temperature, the emission lifetimes of $\mathbf{1}$ and $\mathbf{2}$ are 15.5 and $9.4 \mu \mathrm{s}$, the quantum efficiency being 18 and $56 \%$, respectively. On account of temperature-dependent experimental data, the phenomenon was tentatively ascribed to alteration of the emission nature from thermally activated delayed fluorescence at $300 \mathrm{~K}$ to phosphoresce at $77 \mathrm{~K}$.
\end{abstract}

Keywords: Ag(I) complexes; metal-organic coordination polymers; luminescence; thermally activated delayed fluorescence; phosphorescence; pyrimidylphosphines

\section{Introduction}

Recently, $\mathrm{Ag}(\mathrm{I})$-based metal-organic compounds have attracted increased attention as promising antibacterial agents [1,2], luminescent sensorics [3,4], and potential emitters for lighting application [5-7]. The rich coordination abilities of $\mathrm{Ag}(\mathrm{I})$ ion coupled with easy accessibility of the organic ligands provide ample opportunities for the design of most diverse coordination architectures covering both simple molecules and sophisticated metal-organic frameworks [8-13]. The charge balancing anions $\left(\mathrm{NO}_{3}{ }^{-}, \mathrm{OAc}^{-}, \mathrm{OTf}^{-}, \mathrm{ClO}_{4}^{-}, \mathrm{BF}_{4}^{-}, \mathrm{PF}_{6}^{-}\right.$, halides, etc.) can also determine the structure of products, which are self-assembled via the reactions of $\mathrm{Ag}(\mathrm{I})$ precursors with organic ligands [14-16]. Remarkably, such giant structural diversity of the $\mathrm{Ag}(\mathrm{I})$ compounds provides various tools for tuning their functional properties. For instance, they can be regulated by adjusting the electronic properties of organic ligands. Not the least, of the factors are supramolecular interactions of $\mathrm{Ag} \cdots \mathrm{Ag}$, $\mathrm{Ag} \cdots \pi$, and $\mathrm{Ag}$...X kind, which also can influence the properties of the $\mathrm{Ag}(\mathrm{I})$ compounds, e.g., luminescence [17-21].

Concerning luminescence of silver(I) metal-organic compounds, it was almost neglected for a long time, probably because of the preconception on photosensitivity of this class in principle. It was not until fairly recently the $\mathrm{Ag}(\mathrm{I})$ complexes were recognized as promising emitters, which can exhibit enhanced quantum efficiency coupled with short decay time [22-27]. Note that the luminescent properties of $\mathrm{Ag}(\mathrm{I})$ complexes primarily depend on the structure of the ligand environment. Compared to $\mathrm{Cu}(\mathrm{I})$ complexes showing a metal-to-ligand charge transfer (MLCT) luminescence [28,29], the $\mathrm{Ag}(\mathrm{I})$ analogues commonly emit metal-perturbed ligand-centered fluorescence [30-32], ligand-centered 
phosphorescence [33], or dual emission [34]. This stems from the fact that the MLCT excitation is hampered for $\mathrm{Ag}(\mathrm{I})$ complexes because of the higher ionization potential of $\mathrm{Ag}^{+}$ion in comparison with the $\mathrm{Cu}^{+}$one [35]. This restriction, however, can be overcome using highly electron-donating ligands (e.g., phosphines) coupled with $\pi$-acceptors (chelating diimines, azines, etc.). On account of highly electron-donating ligands, the silver $\mathrm{d}^{10}$ orbitals begin to contribute to HOMO and near-HOMO, while the $\pi$-acceptors facilitate charge transfer from the metal. As a result, $\left(M+L^{\prime}\right) L C T$ excited states can be generated, thereby inducing thermally activated delayed fluorescence (TADF) in $\mathrm{Ag}(\mathrm{I})$ compounds [22-27,36-42]. In the context of OLED application, it is relevant to note that the (M+ $\left.\mathrm{L}^{\prime}\right) \mathrm{LCT}$ emission of $\mathrm{Ag}(\mathrm{I})$ benefits over that of $\mathrm{Cu}(\mathrm{I})$ analogues since the former $(i)$ is shorter in the lifetimes [36,41,42], and (ii) generally appears in the higher energy domain [36,37,39,43-45]. On the whole, $\mathrm{Ag}(\mathrm{I})$ compounds that emit apparent luminescence at ambient temperature, especially, that of TADF nature, are still rare.

Herein, we report on the synthesis and investigation of two $\mathrm{Ag}(\mathrm{I})$ compounds derived from 4,6-bis(diphenylphosphino)pyrimidine and $\mathrm{AgNO}_{3}$ or $\mathrm{AgBF}_{4}$. Both compounds manifest pronounced thermochromic luminescence, which appears as a reversible changing of the emission color from yellow at $300 \mathrm{~K}$ to orange/red at $77 \mathrm{~K}$. It should be noted in this regard that the $\mathrm{Ag}(\mathrm{I})$ complexes endowed with such property are very limited in number [13,46-49].

\section{Results and Discussion}

\section{Synthesis and Characterization}

The starting ligand, 4,6-bis(diphenylphosphino)pyrimidine (L), has been synthesized by the treatment of 2,6-dichloropyrimidine with 2 equiv. of lithium diphenylphosphide [50]. The ligand has been tested in the reaction with $\mathrm{AgNO}_{3}$ and $\mathrm{AgBF}_{4}$ in acetonitrile using different reactant's molar ratios. It has been revealed that the interaction of $\mathrm{AgNO}_{3}$ with ligand $\mathrm{L}$ in a 1:1 molar ratio affords dinuclear complex $\left[\mathrm{Ag}_{2} \mathrm{~L}_{2}(\mathrm{MeCN})_{2}\left(\mathrm{NO}_{3}\right)_{2}\right](\mathbf{1})$ isolated as solvate $\mathbf{1} \cdot \mathrm{MeCN}$ (Scheme 1). Meanwhile, using $\mathrm{AgBF}_{4}$ under similar conditions, the reaction provides cationic $1 \mathrm{D}$ coordination polymer $(\mathrm{CP})$, $\left[\mathrm{Ag}_{2} \mathrm{~L}(\mathrm{MeCN})_{3}\right]_{n}\left(\mathrm{BF}_{4}\right)_{2 n}$ (2) that also crystallizes as solvate $2 \cdot \mathrm{MeCN}$ (Scheme 1). The preparative yields of products $\mathbf{1}$ and 2 are 69 and $91 \%$, respectively.

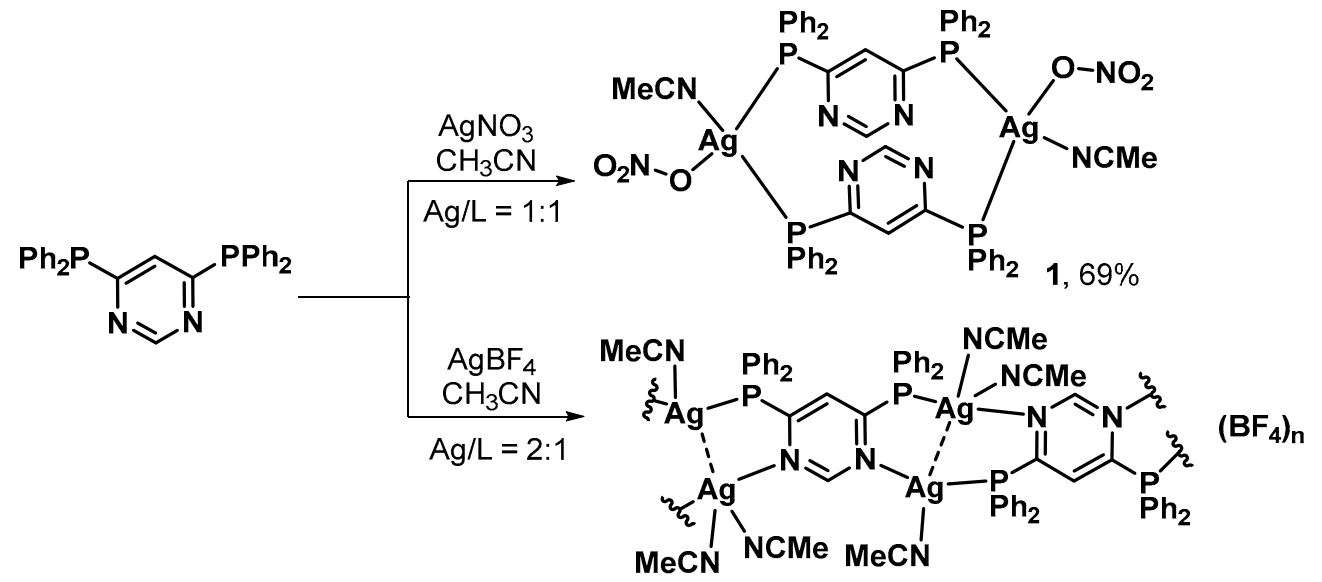

2, $91 \%$

Scheme 1. Synthesis of compounds 1 and 2.

The products obtained are off-white powders, which are well soluble in acetonitrile. Upon storage on air, both $\mathbf{1} \cdot \mathrm{MeCN}$ and $2 \cdot \mathrm{MeCN}$ easily lose acetonitrile molecules. Note that the desolvation is reversible: the recrystallization of the powders formed from acetonitrile leads again to the crystals of the above solvates. Both compounds have been characterized by single crystal X-ray diffractometry (sc-XRD), FT-IR, and UV-Vis abortion spectroscopy. 
Complex $1 \cdot \mathrm{MeCN}$ crystallizes in the monoclinic $P 2_{1} / n$ space group with one half molecule per asymmetric unit. As seen from Figure 1, the scaffold of $\mathbf{1}$ is formed by two Ag atoms bridged by two ligands $\mathrm{L}$ through phosphorus atoms so that the pyrimidine rings become coplanar. The latter are sandwiched in a "head-to-tail" manner with the distance between the average planes being $3.861 \AA$. The $\mathrm{O}$ atom of the $\mathrm{NO}_{3}$ group and acetonitrile $\mathrm{N}$ atom complete the coordination sphere of $\mathrm{Ag} 1$ and $\mathrm{Ag} 2$ atoms to the distorted $\left\{\mathrm{Ag} @ \mathrm{P}_{2} \mathrm{ON}\right\}$ tetrahedron. The bond lengths around metal atoms are comparable with those of most related $\mathrm{Ag}(\mathrm{I})$ complexes [51-53]. In the crystal, molecules of $\mathbf{1}$ are associated together and with MeCN molecules via weak $\mathrm{C}-\mathrm{H} \cdots \mathrm{O}$ and $\mathrm{C}-\mathrm{H} \cdots \mathrm{C}$ contacts forming $3 \mathrm{D}$ supramolecular structure.

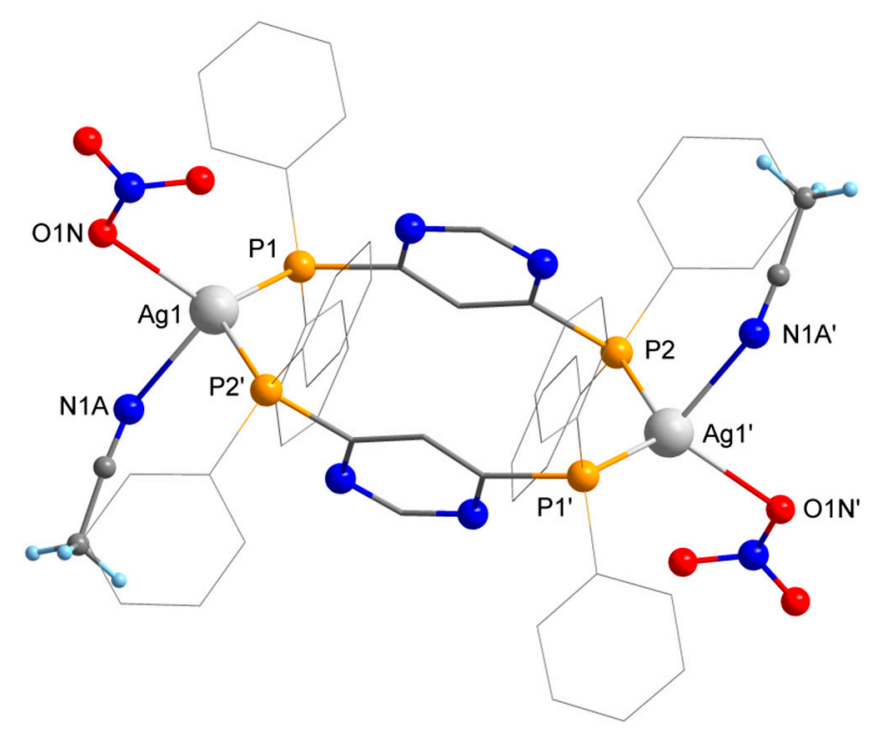

Figure 1. Molecular structure of $1 \cdot \mathrm{MeCN}$. The aromatic $\mathrm{H}$ atoms and solvate molecules are omitted. Selected bond lengths $(\AA)$ and angles $\left(^{\circ}\right)$ : Ag1-P1 2.4224(13), Ag1-P2' 2.4461(13), Ag1-O1N 2.273(9), Ag1-N1A 2.493(8); P1-Ag1-P2' 118.48(4), P1-Ag1-O1N 123.4(4), P1-Ag1-N1A 107.0(3), P2'-Ag1-O1N 110.9(3), P2'-Ag1-N1A 96.8(3), O1N-Ag1-P1 134.1(3), O1N-Ag1-N1A 79.8(4). Symmetry code ('): $1-x, 1-y, 1-z$.

$\mathrm{CP} 2 \cdot \mathrm{MeCN}$ crystallizes in the orthorhombic $P 2_{1} 2_{1} 2_{1}$ space group, and its crystals contain zig-zag chains propagating along $a$ axis. The chains are built up from alternating ligand molecules and $\left[\mathrm{Ag}_{2}(\mathrm{MeCN})_{3}\right]$ units, which are linked via $\mathrm{Ag}-\mathrm{N}$ and $\mathrm{Ag}-\mathrm{P}$ bonds (Figure 2). The metal atoms of the $\left[\mathrm{Ag}_{2}(\mathrm{MeCN})_{3}\right]$ units are bridged by two P,N-faces of the adjacent ligands $\mathrm{L}$ in a "head-to-tail" fashion. The formed eight-membered cycles feature short Ag...Ag contact of 3.3352(4) $\AA$ that is consistent with twice van der Waals radius of $\mathrm{Ag}$ atom (3.44 $\AA$ [54]). Both Ag1 and Ag2 atoms are ligated by one $\mathrm{MeCN}$ molecule $\left(\mathrm{d}_{\mathrm{Ag}-\mathrm{N}} \approx 2.33 \AA\right.$ ); besides, a second MeCN molecule is weakly associated $\left(\mathrm{d}_{\mathrm{Ag}-\mathrm{N}} \approx 2.65 \AA\right.$ ) with Ag1 atom. As a result, Ag1 atom adopts a T-shaped $\left\{\mathrm{Ag} @ \mathrm{~N}_{2} \mathrm{P}\right\}$ geometry, while Ag2 center has a distorted see-saw $\left\{\mathrm{Ag} @ \mathrm{~N}_{3} \mathrm{P}\right\}$ environment. The $\mathrm{Ag}-\mathrm{N}_{\mathrm{L}}$ and $\mathrm{Ag}-\mathrm{P}$ distances are nearly the same as those in $1 \cdot \mathrm{MeCN}$. The non-coordinated tetrafluoroborate anions and $\mathrm{MeCN}$ solvate molecules are associated with the $\left[\mathrm{Ag}_{2} \mathrm{~L}(\mathrm{MeCN})_{3}\right]_{n}$ chains by means of van der Waals contacts such as $\mathrm{C}-\mathrm{H} \cdots \mathrm{F}, \mathrm{C}-\mathrm{H} \cdots \mathrm{N}, \mathrm{Ag} \cdots \mathrm{F}$, and $\mathrm{C} \cdots \mathrm{F}$.

FT-IR spectra of solid $\mathbf{1}$ and $\mathbf{2}$ are in agreement with sc-XRD data, showing characteristic vibrations of the ligand $\mathrm{L}$ along with stretching vibrations of the counter-ions (Figure S1). The N-O and B-F stretchings of the $\mathrm{NO}_{3}{ }^{-}$and $\mathrm{BF}_{4}{ }^{-}$groups appear as strong bands at 1380-1417 and 950-1200 cm${ }^{-1}$, correspondingly. The solid state UV-Vis spectra of $\mathbf{1}$ and $\mathbf{2}$ (plotted as Kubelka-Munk function, Figure S2) display broad bands expanding from the far-UV edge and falling close at about 400 and $440 \mathrm{~nm}$, respectively (Figure S2). Each absorption band has two pronounced shoulders. The high-energy (HE) shoulders, with $\lambda_{\max } \approx 280 \mathrm{~nm}$, are nearly the same for both compounds, while the low-energy (LE) 
ones maximize at $\approx 350 \mathrm{~nm}$ for $\mathbf{1}$ and at $\approx 390 \mathrm{~nm}$ for 2 . Considering the literature data [38], the HE absorption band can be attributed to intraligand $\pi-\pi^{*}$ and $n-\pi^{*}$ transitions. The LE band is likely associated with promotions of MLCT kind, which is typical for emissive Ag(I) complexes [22-27,36-40].

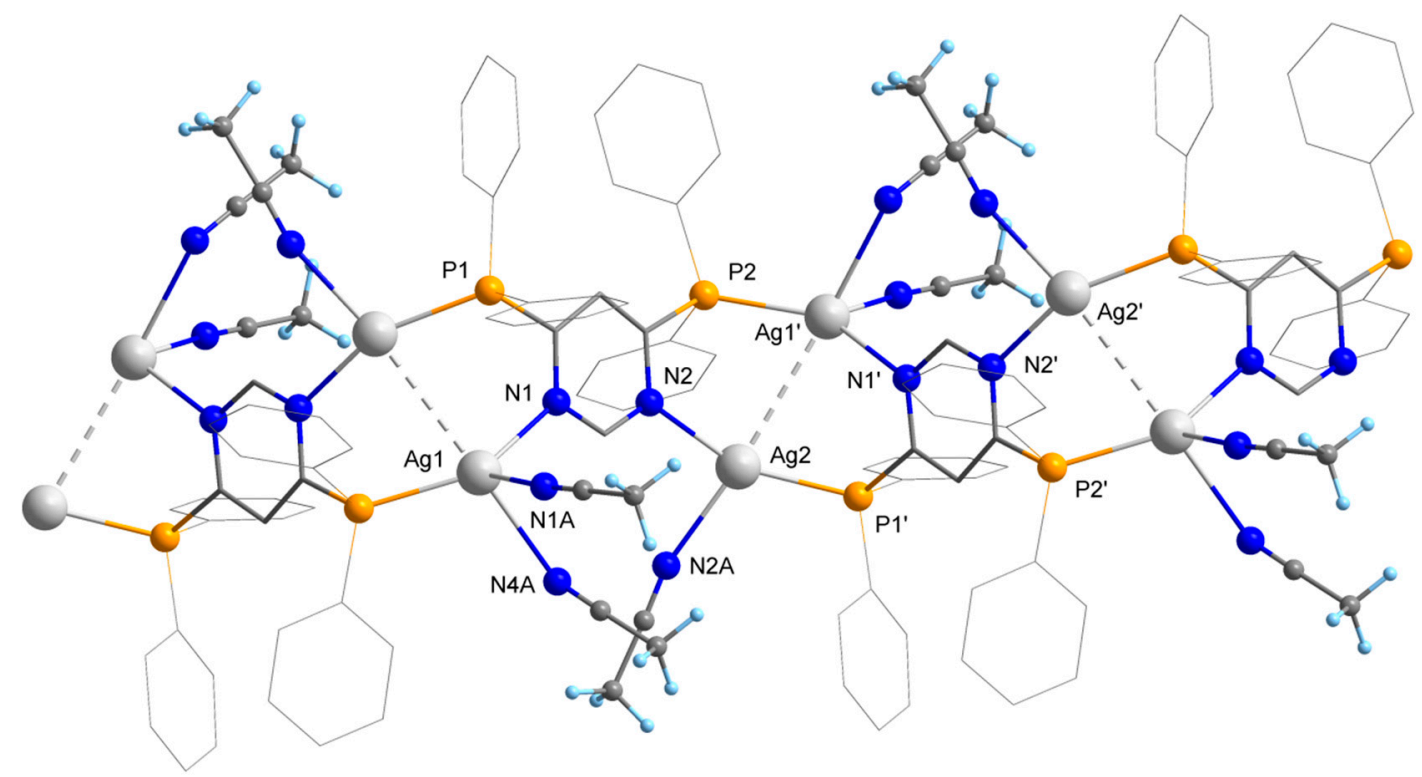

Figure 2. A fragment of the $1 \mathrm{D}$ chain of $2 \cdot \mathrm{MeCN}$. The aromatic $\mathrm{H}$ atoms, $\left[\mathrm{BF}_{4}\right]^{-}$counterions and solvate molecules are omitted. Selected bond lengths $(\AA)$ and angles $\left({ }^{\circ}\right)$ : Ag1'‥Ag2 3.3352(4), Ag1'-P2 2.3943(9), Ag1-N1 2.309(3), Ag1-N1A 2.320(4), Ag1-N4A 2.655(4), Ag2-P1' 2.3622(9), Ag2-N2 2.242(3), Ag2-N2A 2.351(4); P2-Ag1'-Ag2 69.98(2), N1-Ag1-N1A 98.43(11), N1-Ag1-N4A 87.69(10), N1A-Ag1-N4A 81.28(13), P1'-Ag2-Ag1' 72.95(2), N2-Ag2-Ag1' 86.93(7), N2-Ag2-P1' 152.18(7), N2-Ag2-N2A 92.88(12), N2A-Ag2-Ag1' 165.92(12), N2A-Ag2-P1' 111.31(9). Symmetry code ('): $0.5+x, 1.5-y, 1-z$.

When UV-irradiated, solid compounds 1 and 2 exhibit yellow luminescence at ambient temperature. Upon cooling down to liquid nitrogen temperature, the luminescence strongly enhances, and its color changes to red-orange (for $\mathbf{1}$ ) or red (for 2) (Figures $3 \mathrm{~d}$ and $4 \mathrm{~d}$ ). The thermochromic luminescence found appears to be reversible: warming the samples to $300 \mathrm{~K}$ recovers the initial emission chromaticity. Inspirited by these noticeable findings, we have studied the emission properties of the titled compounds at 77-300 K range. Temperature-dependent emission and excitation spectra of $\mathbf{1}$ and $\mathbf{2}$ are plotted in Figures 3 and 4, and the corresponding photophysical data are summarized in Table 1. As seen from the graphs, the emission spectra of 1 and 2 contain a broad band maximized at about 550 and $580 \mathrm{~nm}$, accordingly. The corresponding emission colors on the CIE chromaticity diagram are consistent with those observed by the naked eye. The associated emission lifetimes ( $\left.\tau_{\mathrm{obs}}\right)$ of $\mathbf{1}$ and $\mathbf{2}$ measured at $300 \mathrm{~K}$ are 15.5 and $9.4 \mu \mathrm{s}$, and the photoluminescence quantum yields $\left(\Phi_{\mathrm{PL}}\right)$ are 18 and 56\%, respectively. The excitation profiles of 1 and 2 are presented by smooth bands that fall close at about 420 and $440 \mathrm{~nm}$ (Figures $3 b$ and $4 b$ ). The excitation curves, therefore, resemble the absorption patterns (Figure S2). Note that the compounds studied do not possess excitation-dependent properties, which are quite common for $\mathrm{Ag}(\mathrm{I})$ complexes [55-57]. When the temperature is gradually lowered to $77 \mathrm{~K}$, the emission bands of 1 and 2 are red-shifted by 30 and $22 \mathrm{~nm}$ (Figures $3 \mathrm{a}$ and $4 \mathrm{a}$ ), thereby changing the emission color to red-orange and red, respectively (Figure 3c,d). Simultaneously, the lifetimes rise to $3970 \mu$ s (1) and $300 \mu \mathrm{s}(2)$. 


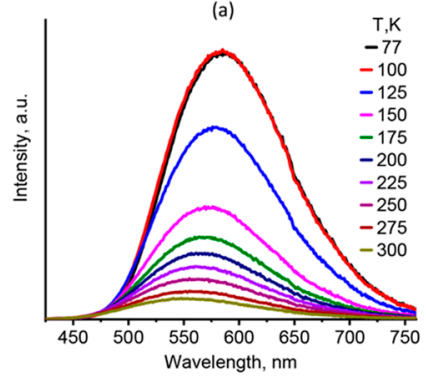

(c)

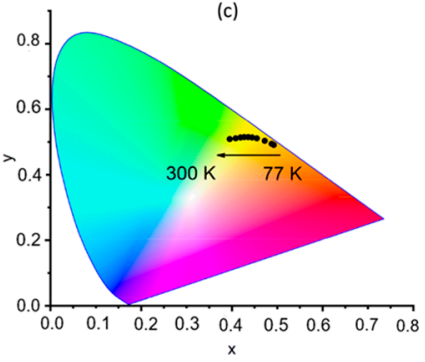

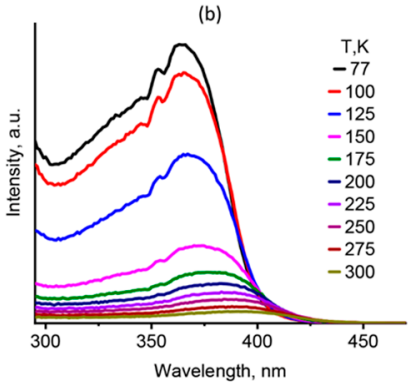

(d)

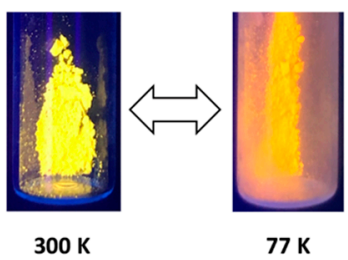

Figure 3. (a) Temperature-dependent emission spectra of $\mathbf{1}\left(\lambda_{\mathrm{ex}}=385 \mathrm{~nm}\right)$; (b) temperature-dependent excitation spectra of $\mathbf{1}\left(\lambda_{\mathrm{em}}=580 \mathrm{~nm}\right)$; (c) temperature dependence of the emission chromaticity of 1 $\left(\lambda_{\mathrm{ex}}=385 \mathrm{~nm}\right) ;(\mathbf{d})$ emission color of sample 1 at 300 and $77 \mathrm{~K}$.

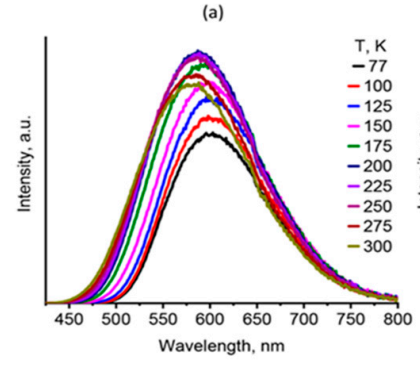

(c)

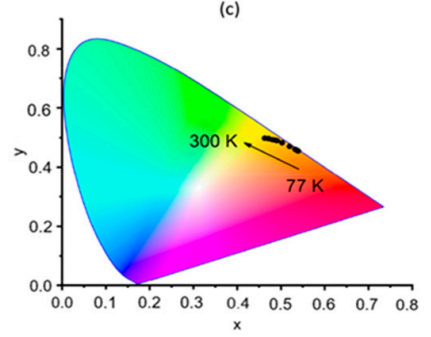

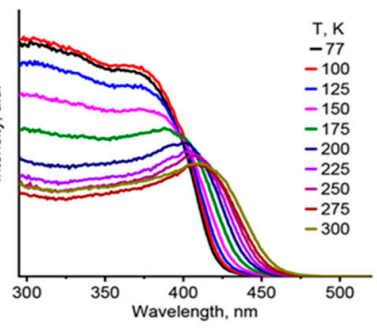

(d)

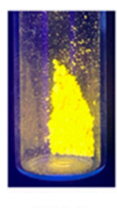

$300 \mathrm{~K}$

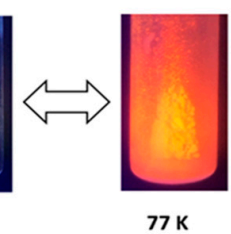

Figure 4. (a) Temperature-dependent emission spectra of $2\left(\lambda_{\mathrm{ex}}=410 \mathrm{~nm}\right)$; (b) temperature-dependent excitation spectra of $2\left(\lambda_{\mathrm{em}}=580 \mathrm{~nm}\right)$; (c) temperature dependence of the emission chromaticity of 2 $\left(\lambda_{\mathrm{ex}}=385 \mathrm{~nm}\right) ;(\mathbf{d})$ emission color of sample 2 at 300 and $77 \mathrm{~K}$.

Table 1. Photophysical data for solid 1 and 2.

\begin{tabular}{ccc}
\hline & $\mathbf{1}$ & $\mathbf{2}$ \\
\hline$\lambda_{\max }(300 \mathrm{~K})(\mathrm{nm})$ & 550 & 580 \\
$\Phi_{\mathrm{PL}}(300 \mathrm{~K})(\%)$ & $18^{\mathrm{a}}$ & $56^{\mathrm{b}}$ \\
$\tau(300 \mathrm{~K})(\mu \mathrm{s})$ & 15.5 & 9.4 \\
$\lambda_{\max }(77 \mathrm{~K})(\mathrm{nm})$ & 580 & 602 \\
$\tau(77 \mathrm{~K})(\mu \mathrm{s})$ & 3970 & 300 \\
\hline${ }^{\mathrm{a}} \lambda_{\mathrm{ex}}=365 \mathrm{~nm}{ }^{\mathrm{b}} \lambda_{\mathrm{ex}}=410 \mathrm{~nm}$.
\end{tabular}


Taken together, these observations suggest that TADF is likely responsible for the room temperature emission of 1 and 2 . The temperature dependence of the lifetimes, $\tau_{\text {obs }}(\mathrm{T})$, measured in $77-300 \mathrm{~K}$ window, supports this suggestion, following the equation intended for the TADF model [58]:

$$
\tau_{o b s}(T)=\left(3+\exp \left(-\frac{\Delta E_{\mathrm{ST}}}{k_{B} T}\right)\right) /\left(\frac{3}{\tau_{T}}+\frac{1}{\tau_{S}} \exp \left(-\frac{\Delta E_{\mathrm{ST}}}{k_{B} T}\right)\right)
$$

wherein $\tau_{S}$ and $\tau_{T}$ are the lifetimes of prompt fluorescence and phosphorescence, respectively, $\Delta E_{S T}$ is the energy gap between the respective excited states $\left(\mathrm{S}_{1}\right.$ and $\left.\mathrm{T}_{1}\right)$, and $k_{B}$ is the Boltzmann constant. Applying this equation for fitting the datasets of Figure 5, the following values have been roughly estimated for 1: $\Delta E\left(S_{1}-T_{1}\right)=750 \mathrm{~cm}^{-1}$, fluorescence lifetime $\tau\left(S_{1}\right)=400 \mathrm{~ns}$, and phosphorescence lifetime $\tau\left(\mathrm{T}_{1}\right)=4000 \mu \mathrm{s}$. Analogously, the following values have been estimated for 2: $\Delta \mathrm{E}\left(\mathrm{S}_{1}-\mathrm{T}_{1}\right)=1000 \mathrm{~cm}^{-1}, \tau\left(\mathrm{S}_{1}\right)=35 \mathrm{~ns}$, and $\tau\left(\mathrm{T}_{1}\right)=300 \mu \mathrm{s}$. It should be emphasized that the given $\Delta \mathrm{E}\left(\mathrm{S}_{1}-\mathrm{T}_{1}\right)$ values are purely evaluative because the Eq. 1 can be applied correctly when the emission quantum yields do not change much than the investigated temperature range [58]. Nevertheless, the estimated $\Delta \mathrm{E}\left(\mathrm{S}_{1}-\mathrm{T}_{1}\right)$ magnitudes agree well with the common values for TADF-emitting $\mathrm{Ag}(\mathrm{I})$ and $\mathrm{Cu}(\mathrm{I})$ complexes, thus allowing to assume manifestation of TADF by $\mathbf{1}$ and $\mathbf{2}$.

(a)

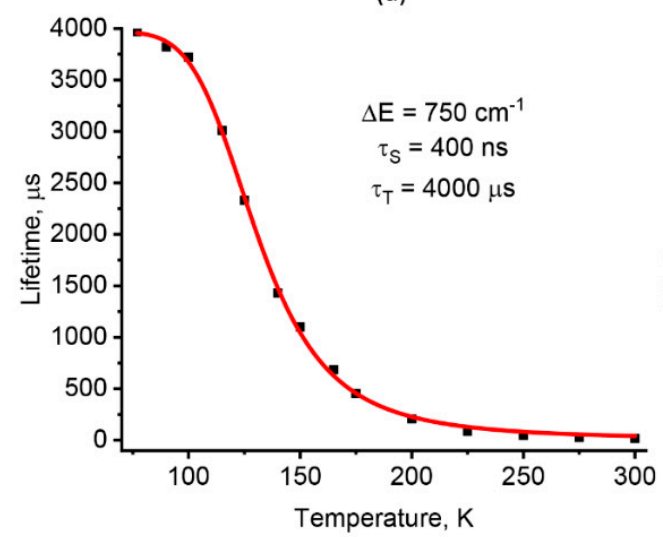

(b)

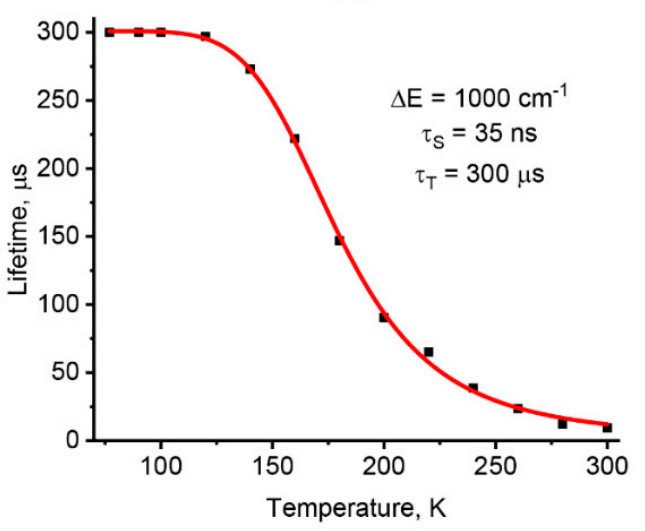

Figure 5. (a) Temperature dependence of the emission lifetimes for $\mathbf{1}\left(\lambda_{\mathrm{ex}}=385 \mathrm{~nm}, \lambda_{\mathrm{em}}=550 \mathrm{~nm}\right)$, and $(\mathbf{b})$ for $2\left(\lambda_{\mathrm{ex}}=410 \mathrm{~nm}, \lambda_{\mathrm{em}}=580 \mathrm{~nm}\right)$.

As seen from Figure 5, the luminescence of both compounds at ambient temperature represents TADF because the $\tau_{\text {obs }}(T)$ curves attain the high-temperature plateau. The pure phosphorescence begins to appear when the $\tau_{\mathrm{obs}}(\mathrm{T})$ curve reaches the low-temperature plateau. In the case of 2 , it occurs below $120 \mathrm{~K}$, while complex 1 , possessing a narrower $\Delta \mathrm{E}\left(\mathrm{S}_{1}-\mathrm{T}_{1}\right)$ gap, emits pure phosphorescence at $77 \mathrm{~K}$ and below. On the drop-down range of the $\tau_{\mathrm{obs}}(\mathrm{T})$ curves, the contribution of the TADF gradually increases up to $\sim 100 \%$ at $300 \mathrm{~K}$, owing to the thermal population of the higher-lying $\mathrm{S}_{1}$ state from the $\mathrm{T}_{1}$ state. As a result, the emission energy shifts in the blue region upon warming from 77 to $300 \mathrm{~K}$, resulting in thermochromic luminescence of $\mathbf{1}$ and $\mathbf{2}$. Considering the literature data on the related $\operatorname{Ag}(\mathrm{I})$ complexes exhibiting TADF [22-27,36-42], we believe that the $\mathrm{S}_{1}$ and $\mathrm{T}_{1}$ excited states of 1 and 2 are of MLCT or $\left(M+L^{\prime}\right)$ LCT nature. The DFT computations performed on complex 1 support this suggestion revealing that HOMO and near-HOMOs are contributed by silver d-orbitals and p-orbitals of nitrate oxygen atoms, while LUMO and near-LUMOs are pure pyrimidine $\pi$-orbitals (Figure S10). Note the previously reported Ag(I) complexes feature a similar HOMO/LUMO distribution pattern [22-27,36-42]. Thus, it can be assumed that the emissive excited state of 1 has a 1,3 $\left(\mathrm{M}+\mathrm{L}^{\prime}\right) \mathrm{LCT}$ character $\left(\mathrm{L}^{\prime}=\mathrm{NO}_{3}\right.$, and $\mathrm{L}=$ pyrimidyldiphosphine $)$. 


\section{Materials and Methods}

\subsection{General}

Synthesis of the ligand L was performed under argon atmosphere, while the compounds $\mathbf{1}$ and 2 were prepared under ambient conditions. $\mathrm{AgNO}_{3}(\geq 99.9 \%$, Aldrich, St. Louis, Missouri, $\mathrm{MO}, \mathrm{USA}), \mathrm{AgBF}_{4}$ ( $\geq 99.9 \%$, Aldrich), $n$-BuLi (2.5 M in hexanes, Aldrich), 4,6-dichloropyrimidine (97\%, Aldrich), and diphenylphosphine (98\%, Aldrich) were used as purchased. Prior to use, commercial tetrahydrofuran (THF, anhydrous, $\geq 99.9 \%$, Aldrich) was purified by distillation over sodium/benzophenone under argon flow. Acetonitrile and dichloromethane were distilled over phosphorus pentoxide.

FT-IR spectra were measured on a Bruker Vertex 80 spectrometer (Bruker, Billerica, Massachusetts, MA, USA) at ambient temperature. The microanalyses were performed on a MICRO cube analyzer.

${ }^{1} \mathrm{H},{ }^{13} \mathrm{C}$, and ${ }^{31} \mathrm{P}\left\{{ }^{1} \mathrm{H}\right\}$ NMR spectra were recorded using a Bruker AV-500 spectrometer at 500.13, 125.8 MHz and 202.46 MHz, respectively, with solvent peaks as reference. The ${ }^{31} \mathrm{P}\left\{{ }^{1} \mathrm{H}\right\}$ NMR shifts are expressed with respect to $85 \% \mathrm{H}_{3} \mathrm{PO}_{4} / \mathrm{D}_{2} \mathrm{O}$ as an external standard.

The microanalyses were performed on a MICRO cube analyzer Photoluminescence spectra were recorded on a Fluorolog 3 spectrometer (Horiba Jobin Yvon, Kyoto, Japan) with a cooled PC177CE-010 photon detection module equipped with an R2658 photomultiplier. The luminescence decays (Figures S5 and S6) were measured on the same instrument. The absolute values of PLQYs were recorded using a Fluorolog 3 Quanta-phi device (Horiba Jobin Yvon). The luminescence quantum yield at $77 \mathrm{~K}$ was obtained relative to the quantum yield of the same sample at $300 \mathrm{~K}$. Independently, these relative quantum yields were calibrated by using the absolute PLQY values measured at $77 \mathrm{~K}$. Temperature dependences of luminescence were carried out using Optistat DN optical cryostats (Oxford Instruments, Abingdon, UK).

The solid-state reflectance spectra were recorded on a Shimadzu UV-3101 spectrophotometer (Shimadzu Corporation, Kyoto, Japan). Samples were prepared by a thorough grinding of a mixture of a complex (ca. $2 \mathrm{~mol} \%$ ) with $\mathrm{BaSO}_{4}$. The reflectance data were converted into a spectrum applying a Kubelka-Munk function using $\mathrm{BaSO}_{4}$ as a standard.

DFT computations of 1 were performed using the hybrid B3LYP functional [59] combined with the def2TZVP basis sets [60]. The calculations were performed for single point geometry taken from X-ray coordinates for non-hydrogen atoms. The computations were proceeded using Gaussian 09 suite [61].

\subsection{Synthesis of 4,6-Bis(diphenylphosphino)pyrimidine (L)}

n-BuLi in hexanes $(2.5 \mathrm{M}, 15 \mathrm{~mL})$ was added dropwise to a solution of diphenylphosphine $(6.139 \mathrm{~g}$, $0.033 \mathrm{~mol})$ in absolute THF $(40 \mathrm{~mL})$ at $-20^{\circ} \mathrm{C}$. The mixture was kept at $-20^{\circ} \mathrm{C}$ and stirred for $1 \mathrm{~h}$. Then, at the same temperature, suspension of 4,6-dichloropyrimidine $(2.384 \mathrm{~g}, 0.016 \mathrm{~mol})$ in THF (10 mL) was added dropwise. The resulting mixture was warmed to $40{ }^{\circ} \mathrm{C}$ and stirred for $4 \mathrm{~h}$. After that $\mathrm{H}_{2} \mathrm{O}$ $(50 \mathrm{~mL})$ was added and the quenched mixture was extracted with $\mathrm{CH}_{2} \mathrm{Cl}_{2}(3 \times 30 \mathrm{~mL})$. The organic extracts were washed with $\mathrm{H}_{2} \mathrm{O}(3 \times 10 \mathrm{~mL})$, dried with $\mathrm{Na}_{2} \mathrm{SO}_{4}$, and evaporated in vacuum. The crude product obtained was recrystallized from $\mathrm{MeOH} / \mathrm{CH}_{2} \mathrm{Cl}_{2}(10: 1, v / v)$ to give colorless crystals of L. Yield: $4.087 \mathrm{~g}(57 \%) .{ }^{1} \mathrm{H}$ NMR (500.13 MHz, $\left.\mathrm{CDCl}_{3}\right) \delta 9.20$ (s, 1H, C $\mathrm{C}^{2} \mathrm{H}$ in Pym), 7.35-7.31 (m, 20H in Ph), 6.69 (s, 1H, C $\mathrm{C}^{5} \mathrm{H}$ in Pym). ${ }^{13} \mathrm{C}\left\{{ }^{1} \mathrm{H}\right\} \mathrm{NMR}\left(126 \mathrm{MHz}, \mathrm{CDCl}_{3}\right) \delta 174.4\left(\mathrm{~d}, J=7.0 \mathrm{~Hz}, \mathrm{C}^{4}\right.$ and $\mathrm{C}^{6}$ in Pym), 156.8 (t, $J=9.3 \mathrm{~Hz}, \mathrm{C}^{2}$ in Pym), $134.4(\mathrm{~s}, o-\mathrm{Ph}), 134.3$ (s, o-Ph), 133.6 (d, J = 8.8 Hz, $\left.i-\mathrm{Ph}\right), 132.1$ $\left(\mathrm{d}, J=9.6 \mathrm{~Hz}, \mathrm{C}^{5}\right.$ in Pym), 129.7 (s, p-Ph), 128.9 (d, J = 7.8 Hz, $\left.m-\mathrm{Ph}\right) .{ }^{31} \mathrm{P}\left\{{ }^{1} \mathrm{H}\right\} \mathrm{NMR} \delta(202.47 \mathrm{MHz}$, $\mathrm{CDCl}_{3}$ ) -2.62. FT-IR (KBr, cm $\left.{ }^{-1}\right)$ : $424(\mathrm{w}), 434(\mathrm{w}), 444(\mathrm{~m}), 463(\mathrm{w}), 484(\mathrm{~m}), 500(\mathrm{vs}), 544(\mathrm{w}), 608(\mathrm{w})$, 619 (w), 696 (vs), 743 (vs), 766 (m), 783 (w), 889 (w), 978 (w), 999 (m), $1026(\mathrm{~m}), 1070$ (w), 1097 (m), $1157(\mathrm{w}), 1184(\mathrm{w}), 1260$ (s), 1310 (w), 1331 (w), 1435 (s), 1479 (s), 1535 (s), $1584(\mathrm{w}), 2984$ (vw), 3049 (w), 3071 (vw). 


\section{3. $\left[\mathrm{Ag}_{2} \mathrm{~L}_{2}\left(\mathrm{NO}_{3}\right)_{2}(\mathrm{MeCN})_{2}\right] \cdot \mathrm{MeCN}(\mathbf{1} \cdot \mathrm{MeCN})$}

A solution of $\mathrm{L}(50 \mathrm{mg}, 0.11 \mathrm{mmol})$ and $\mathrm{AgNO}_{3}(20 \mathrm{mg}, 0.11 \mathrm{mmol})$ in $\mathrm{CH}_{3} \mathrm{CN}(1 \mathrm{~mL})$ was stirred at room temperature for $30 \mathrm{~min}$. The precipitated white powder of the $1 \cdot \mathrm{CH}_{3} \mathrm{CN}$ was centrifuged and dried in air. White powder. Yield: $50 \mathrm{mg}(69 \%)$. Single crystals of $1 \cdot \mathrm{CH}_{3} \mathrm{CN}$ were grown by vapor diffusion of diethyl ether into the $\mathrm{CH}_{3} \mathrm{CN}$ solution for overnight. FT-IR (thin film, $\mathrm{cm}^{-1}$ ): $474(\mathrm{~m})$, 505 (s), 692 (vs), 746 (s), 997 (w), 1028 (w), 1099 (m), 1265 (m), 1288 (s), 1385 (s), 1420 (s), 1437 (vs), 1481 (m), 1495 (m), 1539 (vs), 2251 (w), 2294 (vw), 2921 (w), 2936 (vw), 2994 (vw), 3056 (w). Anal. Calcd: $\mathrm{C}_{56} \mathrm{H}_{44} \mathrm{Ag}_{2} \mathrm{~N}_{6} \mathrm{P}_{4} \mathrm{O}_{6}(1236.62) \mathrm{C}, 54.4 ; \mathrm{H}, 3.6 ; \mathrm{N}, 6.8$. Found: $\mathrm{C}, 54.4 ; \mathrm{H}, 3.4 ; \mathrm{N}, 6.7$. Since the solvate 1. $\mathrm{CH}_{3} \mathrm{CN}$ quickly loses the molecules of acetonitrile upon storage, the microanalysis was calculated on $\left[\mathrm{Ag}_{2}(\mathrm{~L})_{2}\left(\mathrm{NO}_{3}\right)_{2}\right]$.

\section{4. $\left[\mathrm{Ag}_{2} \mathrm{~L}(\mathrm{MeCN})_{3}\right]_{n}\left(\mathrm{BF}_{4}\right)_{2 n} \cdot \mathrm{MeCN}(2 \cdot \mathrm{MeCN})$}

A solution of $\mathrm{L}\left(50 \mathrm{mg}, 0.11 \mathrm{mmol}\right.$ ) and $\mathrm{AgBF}_{4}(43 \mathrm{mg}, 0.22 \mathrm{mmol})$ in $\mathrm{CH}_{3} \mathrm{CN}(1 \mathrm{~mL})$ was stirred at room temperature for $30 \mathrm{~min}$. To the resulting solution, diethyl ether $(5 \mathrm{~mL})$ was then added and the precipitate formed was centrifuged and dried in air. White powder. Yield: $100 \mathrm{mg}(91 \%)$. Single crystals of $2 \cdot \mathrm{CH}_{3} \mathrm{CN}$ were grown by vapor diffusion of diethyl ether into the $\mathrm{CH}_{3} \mathrm{CN}$ solution for overnight. FT-IR $\left(\mathrm{cm}^{-1}\right)$ : $478(\mathrm{w}), 507(\mathrm{~m}), 519(\mathrm{~m}), 692(\mathrm{~S}), 746(\mathrm{~m}), 997(\mathrm{~m}), 1063(\mathrm{vs}), 1084(\mathrm{vs})$, $1097(\mathrm{vs}), 1163(\mathrm{w}), 1184(\mathrm{w}), 1287(\mathrm{w}), 1308(\mathrm{w}), 1437(\mathrm{~s}), 1454(\mathrm{w}), 1481(\mathrm{w}), 1497(\mathrm{w}), 1560(\mathrm{~m})$, $1634(\mathrm{w}), 2253(\mathrm{w}), 2298(\mathrm{w}), 2388(\mathrm{w}), 2971(\mathrm{w}), 3009(\mathrm{vw}), 3063(\mathrm{w})$. Anal. Calcd: $\mathrm{C}_{28} \mathrm{H}_{22} \mathrm{Ag}_{2} \mathrm{~B}_{2} \mathrm{~F}_{8} \mathrm{~N}_{2} \mathrm{P}_{2}$ (837.78) C, 40.1; H, 2.6; N, 3.3. Found: $\mathrm{C}, 40.0 ; \mathrm{H}, 2.6 ; \mathrm{N}$, 3.5. Since the solvate $2 . \mathrm{CH}_{3} \mathrm{CN}$ quickly loses the molecules of acetonitrile upon storage, the microanalysis was calculated on $\left[\mathrm{Ag}_{2} \mathrm{~L}\right]\left(\mathrm{BF}_{4}\right)_{2}$.

\subsection{X-ray Crystallography}

Single crystals of $\mathbf{1} \cdot \mathrm{MeCN}$ and $\mathbf{2} \cdot \mathrm{MeCN}$ were grown by diffusion of diethyl ether vapors into a MeCN solutions at ambient temperature for overnight. The X-ray data and the details of the refinement are summarized in Table S1. Diffraction data were collected on an automated Agilent Xcalibur diffractometer equipped with an area AtlasS2 detector (graphite monochromator, $\lambda(\mathrm{Mo} \mathrm{K} \alpha)=0.71073 \AA$, $\omega$-scans, Agilent, Santa Clara, California, CA, USA). Integration, absorption correction, and determination of unit cell parameters were performed using the CrysAlisPro program package [62]. The structures were solved by dual space algorithm (SHELXT [63]) and refined by the full-matrix least squares technique (SHELXL [64]) in the anisotropic approximation (except hydrogen atoms). Positions of hydrogen atoms of organic ligands were calculated geometrically and refined in the riding model.

The crystallographic data and details of the structure refinements are summarized in Table S1. CCDC 2020455 and 2020456 contain the supplementary crystallographic data for this paper. These data can be obtained free of charge from The Cambridge Crystallographic Data Center at http://www.ccdc. cam.ac.uk/data_request/cif.

\section{Conclusions}

Thus, two $\operatorname{Ag}(\mathrm{I})$ metal-organic compounds have been synthesized by the treatment of 4,6-bis(diphenylphosphino)pyrimidine (L) with $\mathrm{AgNO}_{3}$ and $\mathrm{AgBF}_{4}$ in acetonitrile. It has been revealed that the interaction with $\mathrm{AgNO}_{3}$ results in neutral dinuclear complex, $\left[\mathrm{Ag}_{2} \mathrm{~L}_{2}(\mathrm{MeCN})_{2}\left(\mathrm{NO}_{3}\right)_{2}\right]$, while the reaction with $\mathrm{AgBF}_{4}$ produces cationic $1 \mathrm{D}$ zig-zag polymer, $\left[\mathrm{Ag}_{2} \mathrm{~L}(\mathrm{MeCN})_{3}\right]_{n}\left(\mathrm{BF}_{4}\right)_{2 n}$. The structure of the complex is built up from two $\mathrm{Ag}(\mathrm{I})$ ions bridged by the two ligands in a $\mu_{2}-\mathrm{P}, \mathrm{P}^{\prime}$-manner. The $1 \mathrm{D}$ chains of the polymer are assembled by alternating ligand $\left(\mu_{4}-\mathrm{N}, \mathrm{P}, \mathrm{N}^{\prime}, \mathrm{P}^{\prime}\right)$ and $\left[\mathrm{Ag}_{2}(\mathrm{MeCN})_{3}\right]$ units, interconnected through $\mathrm{Ag}-\mathrm{N}$ and $\mathrm{Ag}-\mathrm{P}$ bonds. Both title compounds feature pronounced thermochromic luminescence, which appears as reversible yellow-to-orange changing of the emission color during the cooling-warming cycling (300-77 K). The detailed temperature-dependent photophysical study has shown that the ambient temperature photoluminescence of the above 
compounds may be tentatively ascribed to TADF. At $77 \mathrm{~K}$, they certainly emit pure phosphorescence. The distinct thermochromic behavior of the complexes designed makes them promising materials for luminescent thermometry. From the fundamental viewpoint, the findings reported contribute to coordination chemistry and photophysics of Ag(I)-based metal-organic compounds.

Supplementary Materials: The following are available online at http://www.mdpi.com/2304-6740/8/9/46/s1, Figure S1: FT-IR spectra of 1 and 2 displayed in the fingerprint range; Figure S2: Solid state absorption spectra of 1 and 2 plotted as a Kubelka-Munk function; Figure S3: Temperature dependence of the integral intensity of the emission of $1\left(\lambda_{\mathrm{ex}}=365 \mathrm{~nm}\right)$; Figure S4: Temperature dependences of the integral intensity of the emission of 2 recorded at $\lambda_{\mathrm{ex}}=410 \mathrm{~nm}$ (left) and $\lambda_{\mathrm{ex}}=365 \mathrm{~nm}$ (right); Figure S5: Emission decay profiles of 1 recorded at different temperatures $\left(\lambda_{\mathrm{ex}}=385 \mathrm{~nm}, \lambda_{\mathrm{em}}=550 \mathrm{~nm}\right)$; Figure S6: Emission decay profiles of 2 recorded at different temperatures $\left(\lambda_{\mathrm{ex}}=410 \mathrm{~nm}, \lambda_{\mathrm{em}}=580 \mathrm{~nm}\right)$; Figure S7: ${ }^{1} \mathrm{H}$ NMR spectrum of the ligand $\mathrm{L}\left(\mathrm{CDCl}_{3}\right)$; Figure S8: J-modulated ${ }^{13} \mathrm{C}$ NMR spectrum of the ligand $\mathbf{L}\left(\mathrm{CDCl}_{3}\right)$; Figure S9: ${ }^{31} \mathrm{P}\left\{{ }^{1} \mathrm{H}\right\}$ NMR spectrum of the ligand $\mathbf{L}$ $\left(\mathrm{CDCl}_{3}\right)$; Figure S10: Four lowest unoccupied and 4 highest occupied MOs (iso-value $\left.=0.045\right)$ for the $\mathrm{S}_{0}$ state of the complex 1 calculated at the B3LYP/def2TZVP level; Table S1: X-Ray crystallographic data for $1 \cdot \mathrm{CH}_{3} \mathrm{CN}$ and 2. $\mathrm{CH}_{3} \mathrm{CN}$; the CIF and the checkCIF output files are included in the Supplementary Materials.

Author Contributions: Project conceptualization, administration, supervision, writing-review and editing, and funding acquisition, A.V.A.; investigation, writing, data curation, visualization, M.P.D. and A.S.B.; crystallography, D.G.S. All authors have read and agreed to the published version of the manuscript.

Funding: This work was supported by Russian Science Foundation (Project 18-73-10086).

Acknowledgments: We thank Evgeniya Doronina (A.E. Favorsky Irkutsk Institute of Chemistry, Irkutsk, Russian Federation) for help with the DFT calculations.

Conflicts of Interest: The authors declare no conflict of interest.

\section{References}

1. Medici, S.; Peana, M.; Crisponi, G.; Nurchi, V.M.; Lachowicz, J.I.; Remelli, M.; Zoroddu, M.A. Silver coordination compounds: A new horizon in medicine. Coord. Chem. Rev. 2016, 327-328, 349-359. [CrossRef]

2. Kulovi, S.; Dalbera, S.; Das, S.; Zangrando, E.; Puschmann, H.; Dalai, S. New silver(I) coordination polymers with hetero donor ligands: Synthesis, structure, luminescence study and photo-catalytic behavior. ChemistrySelect 2017, 2, 9029-9036. [CrossRef]

3. Rawashdeh-Omary, M.A.; Rashdan, M.D.; Dharanipathi, S.; Elbjeirami, O.; Ramesh, P.; Rasika Dias, H.V. On/off luminescence vapochromic selective sensing of benzene and its methylated derivatives by a trinuclear silver(I) pyrazolate sensor. Chem. Commun. 2011, 47, 1160-1162. [CrossRef] [PubMed]

4. Wang, Y.; Shi, Y.; Zou, X.; He, Y.; Wang, X. Pyridylphosphine supported Ag(I) and Cu(I) complexes for detection of alcohols and nitriles via structural transformations from 1D to 0D. CrystEngComm 2019, 21, 5595-5601. [CrossRef]

5. Fresta, E.; Carbonell-Vilar, J.M.; Yu, J.; Armentano, D.; Cano, J.; Viciano-Chumillas, M.; Costa, R.D. Deciphering the electroluminescence behavior of silver(I)-complexes in light-emitting electrochemical cells: Limitations and solutions toward highly stable devices. Adv. Funct. Mater. 2019, 29, 1901797. [CrossRef]

6. Moudam, O.; Tsipis, A.C.; Kommanaboyina, S.; Horton, P.N.; Coles, S.J. First light-emitting electrochemical

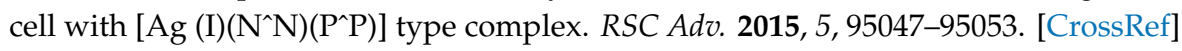

7. Lu, Z.; Cheng, Y.; Fan, W.; Yang, S.; Liu, X.; Qin, Y.; Zhao, R.; Zheng, L.; Zhang, H. A stable silver metallacage with solvatochromic and mechanochromic behavior for white LED fabrication. Chem. Commun. 2019, 55, 8474-8477. [CrossRef]

8. Khlobystov, A.N.; Blake, A.J.; Champness, N.R.; Lemenovskii, D.A.; Majouga, A.G.; Zyk, N.V.; Schröder, M. Supramolecular design of one-dimensional coordination polymers based on silver(I) complexes of aromatic nitrogen-donor ligands. Coord. Chem. Rev. 2001, 222, 155-192. [CrossRef]

9. Sharma, S.; Chakrahari, K.K.; Saillard, J.-Y.; Liu, C.W. Structurally precise dichalcogenolate-protected copper and silver superatomic nanoclusters and their alloys. Acc. Chem. Res. 2018, 51, 2475-2483. [CrossRef]

10. Huang, R.; Wei, Y.; Dong, X.; Wu, X.-H.; Du, C.-X.; Zang, S.-Q.; Mak, T.C.W. Hypersensitive dual-function luminescence switching of a silver-chalcogenolate cluster-based metal-organic framework. Nat. Chem. 2017, 9, 689-697. [CrossRef] 
11. Jin, G.-X.; Zhu, G.-Y.; Sun, Y.-Y.; Shi, Q.-X.; Liang, L.-P.; Wang, H.-Y.; Wu, X.-W.; Ma, J.-P. [Ag-Ag] ${ }^{2+}$ unit-encapsulated trimetallic cages: One-pot syntheses and modulation of argentophilic interactions by the uncoordinated substituents. Inorg. Chem. 2019, 58, 2916-2920. [CrossRef]

12. Chupina, A.V.; Mukhacheva, A.A.; Abramov, P.A.; Sokolov, M.N. Complexation and isomerization of $\left[\beta-\mathrm{Mo}_{8} \mathrm{O}_{26}\right]^{4-}$ in the presence of $\mathrm{Ag}^{+}$and DMF. J. Struct. Chem. 2020, 61, 299-308. [CrossRef]

13. Shmakova, A.A.; Berezin, A.S.; Abramov, P.A.; Sokolov, M.N. Self-assembly of $\mathrm{Ag}^{+} /\left[\mathrm{PW}_{11} \mathrm{NbO}_{40}\right]^{4-}$ complexes in nonaqueous solutions. Inorg. Chem. 2020, 59, 1853-1862. [CrossRef] [PubMed]

14. Wu, J.-Y.; Chao, T.-C.; Zhong, M.-S. Influence of counteranions on the structural modulation of silver-di(3-pyridylmethyl)amine coordination polymers. Cryst. Growth Des. 2013, 13, 2953-2964. [CrossRef]

15. Liu, F.-J.; Sun, D.; Hao, H.-J.; Huang, R.-B.; Zheng, L.-S. Anion-controlled assembly of silver(I)/aminobenzonitrile compounds: Syntheses, crystal structures, and photoluminescence properties. Cryst. Growth Des. 2012, 12, 354-361. [CrossRef]

16. Seward, C.; Chan, J.; Song, D.; Wang, S. Anion dependent structures of luminescent silver(I) complexes. Inorg. Chem. 2003, 42, 1112-1120. [CrossRef] [PubMed]

17. Che, C.-M.; Tse, M.-C.; Chan, M.C.W.; Cheung, K.-K.; Phillips, D.L.; Leung, K.-H. Spectroscopic evidence for argentophilicity in structurally characterized luminescent binuclear silver(I) complexes. J. Am. Chem. Soc. 2000, 122, 2464-2468. [CrossRef]

18. Feazell, R.P.; Carson, C.E.; Klausmeyer, K.K. Variability in the structures of luminescent [2-(aminomethyl)pyridine] silver(I) complexes: Effect of ligand ratio, anion, hydrogen bonding, and $\pi$-stacking. Eur. J. Inorg. Chem. 2005, 2005, 3287-3297. [CrossRef]

19. Matos, C.R.M.O.; Monteiro, F.G.A.; Miranda, F.S.; Pinheiro, C.B.; Bond, A.D.; Ronconi, C.M. Tuning Photoluminescent properties of silver(I)-based coordination networks through their supramolecular interactions. Cryst. Growth Des. 2017, 17, 5965-5974. [CrossRef]

20. Zhan, S.-Z.; Song, H.-Q.; Guo, L.-J.; Sun, R.W.-Y.; Li, D. Structure- and temperature-dependent luminescence properties of threefold interpenetrated networks: Coordination polymers based on dinuclear gridlike silver(I) units. Eur. J. Inorg. Chem. 2017, 2017, 5127-5133. [CrossRef]

21. Liu, S.Q.; Kuroda-Sowa, T.; Konaka, H.; Suenaga, Y.; Maekawa, M.; Mizutani, T.; Ning, G.L.; Munakata, M. Silver(I) coordination polymers of fluorescent oligo (phenylenevinylene) with $\pi-\pi$ stackings: luminescence and conductivity. Inorg. Chem. 2005, 44, 1031-1036. [CrossRef] [PubMed]

22. Jia, J.-H.; Liang, D.; Yu, R.; Chen, X.-L.; Meng, L.; Chang, J.-F.; Liao, J.-Z.; Yang, M.; Li, X.-N.; Lu, C.-Z. Coordination-induced thermally activated delayed fluorescence: From non-TADF donor-acceptor-type ligand to TADF-active Ag-based complexes. Chem. Mater. 2020, 32, 620-629. [CrossRef]

23. Chen, J.; Teng, T.; Kang, L.; Chen, X.-L.; Wu, X.-Y.; Yu, R.; Lu, C.-Z. Highly efficient thermally activated delayed fluorescence in dinuclear $\mathrm{Ag}(\mathrm{I})$ complexes with a bis-bidentate tetraphosphane bridging ligand. Inorg. Chem. 2016, 55, 9528-9536. [CrossRef] [PubMed]

24. Gan, X.-M.; Yu, R.; Chen, X.-L.; Yang, M.; Lin, L.; Wu, X.-Y.; Lu, C.-Z. A unique tetranuclear Ag(I) complex emitting efficient thermally activated delayed fluorescence with a remarkably short decay time. Dalton Trans. 2018, 47, 5956-5960. [CrossRef]

25. Shafikov, M.Z.; Suleymanova, A.F.; Czerwieniec, R.; Yersin, H. Thermally activated delayed fluorescence from $\mathrm{Ag}(\mathrm{I})$ complexes: A route to $100 \%$ quantum yield at unprecedentedly short decay time. Inorg. Chem. 2017, 56, 13274-13285. [CrossRef]

26. Shafikov, M.Z.; Suleymanova, A.F.; Schinabeck, A.; Yersin, H. Dinuclear Ag(I) Complex designed for highly efficient thermally activated delayed fluorescence. J. Phys. Chem. Lett. 2018, 9, 702-709. [CrossRef]

27. Shafikov, M.Z.; Suleymanova, A.F.; Czerwieniec, R.; Yersin, H. Design strategy for Ag(I)-Based thermally activated delayed fluorescence reaching an efficiency breakthrough. Chem. Mater. 2017, 29, 1708-1715. [CrossRef]

28. Czerwieniec, R.; Leitl, M.J.; Homeier, H.H.H.; Yersin, H. Cu(I) complexes-Thermally activated delayed fluorescence. Photophysical approach and material design. Coord. Chem. Rev. 2016, 325, 2-28. [CrossRef]

29. Moussa, M.S.; Khalil, A.M.; Evariste, S.; Wong, H.-L.; Delmas, V.; Le Guennic, B.; Calvez, G.; Costuas, K.; Yam, V.W.-W.; Lescop, C. Intramolecular rearrangements guided by adaptive coordination-driven reactions toward highly luminescent polynuclear $\mathrm{Cu}(\mathrm{I})$ assemblies. Inorg. Chem. Front. 2020, 7, 1334-1344. [CrossRef]

30. Wei, Z.; Wu, X.-H.; Luo, P.; Wang, J.-Y.; Li, K.; Zang, S.-Q. Matrix coordination induced emission in a three-dimensional silver cluster-assembled material. Chem. Eur. J. 2019, 25, 2750-2756. [CrossRef] 
31. Du, L.-Y.; Shi, W.-J.; Hou, L.; Wang, Y.-Y.; Shi, Q.-Z.; Zhu, Z. Solvent or temperature induced diverse coordination polymers of silver(I) sulfate and bipyrazole systems: Syntheses, crystal structures, luminescence, and sorption properties. Inorg. Chem. 2013, 52, 14018-14027. [CrossRef]

32. Durini, S.; Ardizzoia, G.A.; Therrien, B.; Brenna, S. Tuning the fluorescence emission in mononuclear heteroleptic trigonal silver(I) complexes. New J. Chem. 2017, 41, 3006-3014. [CrossRef]

33. Shafikov, M.Z.; Czerwieniec, R.; Yersin, H. Ag(I) complex design affording intense phosphorescence with a landmark lifetime of over 100 milliseconds. Dalton Trans. 2019, 48, 2802-2806. [CrossRef] [PubMed]

34. Xu, Q.-Q.; Dong, X.-Y.; Huang, R.-W.; Li, B.; Zang, S.-Q.; Mak, T.C.W. A thermochromic silver nanocluster exhibiting dual emission character. Nanoscale 2015, 7, 1650-1654. [CrossRef]

35. Hsu, C.-W.; Lin, C.-C.; Chung, M.-W.; Chi, Y.; Lee, G.-H.; Chou, P.-T.; Chang, C.-H.; Chen, P.-Y. Systematic investigation of the metal-structure-photophysics relationship of emissive $\mathrm{d}^{10}$-complexes of group 11 elements: The prospect of application in organic light emitting devices. J. Am. Chem. Soc. 2011, 133, 12085-12099. [CrossRef] [PubMed]

36. Yersin, H.; Leitl, M.J.; Czerwieniec, R. TADF for singlet harvesting: Next generation OLED materials based on brightly green and blue emitting $\mathrm{Cu}(\mathrm{I})$ and $\mathrm{Ag}(\mathrm{I})$ compounds. Proc. SPIE 2014, 9183, 91830N.

37. Osawa, M.; Kawata, I.; Ishii, R.; Igawa, S.; Hashimoto, M.; Hoshino, M. Application of neutral d ${ }^{10}$ coinage metal complexes with an anionic bidentate ligand in delayed fluorescence-type organic light-emitting diodes. J. Mater. Chem. C 2013, 1, 4375-4383. [CrossRef]

38. Artem'ev, A.V.; Shafikov, M.Z.; Schinabeck, A.; Antonova, O.V.; Berezin, A.S.; Bagryanskaya, I.Y.; Plusnin, P.E.; Yersin, H. Sky-blue thermally activated delayed fluorescence (TADF) based on Ag(I) complexes: Strong solvation-induced emission enhancement. Inorg. Chem. Front. 2019, 6, 3168-3176. [CrossRef]

39. Osawa, M.; Hashimoto, M.; Kawata, I.; Hoshino, M. Photoluminescence properties of TADF-emitting three-coordinate silver(I) halide complexes with diphosphine ligands: A comparison study with copper(I) complexes. Dalton Trans. 2017, 46, 12446-12455. [CrossRef]

40. Titov, A.A.; Filippov, O.A.; Smol'yakov, A.F.; Godovikov, I.A.; Shakirova, J.R.; Tunik, S.P.; Podkorytov, I.S.; Shubina, E.S. Luminescent complexes of the trinuclear silver(I) and copper(I) pyrazolates supported with bis(diphenylphosphino) methane. Inorg. Chem. 2019, 58, 8645-8656. [CrossRef] [PubMed]

41. Hamze, R.; Shi, S.; Kapper, S.C.; Ravinson, D.S.M.; Estergreen, L.; Jung, M.-C.; Tadle, A.C.; Haiges, R.; Djurovich, P.I.; Peltier, J.L.; et al. “Quick-silver” from a systematic study of highly luminescent, two-coordinate, $\mathrm{d}^{10}$ coinage metal complexes. J. Am. Chem. Soc. 2019, 141, 8616-8626. [CrossRef]

42. Chotard, F.; Sivchik, V.; Linnolahti, M.; Bochmann, M.; Romanov, A.S. Mono-versus bicyclic carbene metal amide photoemitters: Which design leads to the best performance? Chem. Mater. 2020, 32, 6114-6122. [CrossRef]

43. Ruan, Z.-W.; Zhang, X.; Pang, A.-Y.; Dai, F.-R.; Chen, Z.-N. Blue luminescent silver(I) complexes constructed by 2-diphenylphosphinopyridine and dicyanamide or tricyanomethanide. Inorg. Chem. Commun. 2020, 116, 107916. [CrossRef]

44. Kakizoe, D.; Nishikawa, M.; Degawa, T.; Tsubomura, T. Intense blue emission and a reversible hypsochromic shift of luminescence caused by grinding based on silver(I) complexes. Inorg. Chem. Front. 2016, 3, 1381-1387. [CrossRef]

45. Yersin, H.; Czerwieniec, R.; Shafikov, M.Z.; Suleymanova, A.F. TADF material design: Photophysical background and case studies focusing on $\mathrm{Cu}^{\mathrm{I}}$ and $\mathrm{Ag}^{\mathrm{I}}$ complexes. ChemPhysChem 2017, 18, 3508-3535. [CrossRef] [PubMed]

46. Chakkaradhari, G.; Eskelinen, T.; Degbe, C.; Belyaev, A.; Melnikov, A.S.; Grachova, E.V.; Tunik, S.P.; Hirva, P.; Koshevoy, I.O. Oligophosphine-thiocyanate copper(I) and silver(I) complexes and their borane derivatives showing delayed fluorescence. Inorg. Chem. 2019, 58, 3646-3660. [CrossRef] [PubMed]

47. Crespo, O.; Gimeno, M.; Laguna, A.; Larraz, C. Luminescent silver(I) and copper(I) systems containing pyridyl phosphine bridges. Z. Naturforsch. B 2009, 64, 1525-1534. [CrossRef]

48. Li, S.; Han, M.; Wu, B.; Wang, J.; Zhang, F.-Q.; Zhang, X.-M. Observation of contrary thermo-responsive trend for single crystal and powder samples in mechano-, thermo- and solvato-responsive luminescent cubane $\left[\mathrm{Ag}_{4} \mathrm{I}_{4} \mathrm{~L}_{4}\right]$ cluster. Sci. Rep. 2017, 7, 13058. [CrossRef]

49. Dosen, M.; Kawada, Y.; Shibata, S.; Tsuge, K.; Sasaki, Y.; Kobayashi, A.; Kato, M.; Ishizaka, S.; Kitamura, N. Control of emissive excited states of silver(I) halogenido coordination polymers by a solid solution approach. Inorg. Chem. 2019, 58, 8419-8431. [CrossRef] 
50. Cui, H.-H.; Wu, N.-N.; Wang, J.-Y.; Hu, M.-Q.; Wen, H.-M.; Chen, C.-N. Pyridyl- and pyrimidyl-phosphine-substituted [FeFe]-hydrogenase mimics: Synthesis, characterization and properties. J. Organomet. Chem. 2014, 767, 46-53. [CrossRef]

51. Miller, P.; Nieuwenhuyzen, M.; Charmant, J.P.H.; James, S.L. ROP relationships between coordination polymers and discrete complexes: Discrete bowl-shaped isomers of a 2-dimensional $\left\{\mathrm{M}_{4} \mathrm{~L}_{3}\right\}_{n}$ polymer. CrystEngComm 2004, 6, 408-412. [CrossRef]

52. Cingolani, A.; Effendy; Martini, D.; Pettinari, C.; Skelton, B.W.; White, A.H. Synthesis, spectroscopic and structural characterization of novel adducts of some silver(I) salts with the ambidentate donor $\mathrm{PPh}_{2} \mathrm{py}$. Inorg. Chim. Acta 2006, 359, 2183-2193. [CrossRef]

53. Kuang, S.-M.; Zhang, L.-M.; Zhang, Z.-Z.; Wu, B.-M.; Mak, T.C.W. Synthesis and structural characterization of binuclear silver(I) complexes bridged by three polydentate phosphine ligands. Inorg. Chim. Acta 1999, 284, 278-283. [CrossRef]

54. Bondi, A. van der Waals volumes and radii. J. Phys. Chem. 1964, 68, 441-451. [CrossRef]

55. Zheng, J.; Yu, Y.-D.; Liu, F.-F.; Liu, B.-Y.; Wei, G.; Huang, X.-C. Modulation of argentophilic interactions by bridging amine ligands: Photoluminescence tuneable by excitation energy or temperature. Chem. Commun. 2014, 50, 9000-9002. [CrossRef] [PubMed]

56. Shekhovtsov, N.A.; Vinogradova, K.A.; Berezin, A.S.; Sukhikh, T.S.; Krivopalov, V.P.; Nikolaenkova, E.B.; Bushuev, M.B. Excitation wavelength dependent emission of silver(I) complexes with a pyrimidine ligand. Inorg. Chem. Front. 2020, 7, 2212-2223. [CrossRef]

57. Rogovoy, M.I.; Frolova, T.S.; Samsonenko, D.G.; Berezin, A.S.; Bagryanskaya, I.Y.; Nedolya, N.A.; Tarasova, O.A.; Fedin, V.P.; Artem'ev, A.V. OD to 3D coordination assemblies engineered on silver(I) salts and 2-(alkylsulfanyl)azine ligands: Crystal structures, dual luminescence, and cytotoxic activity. Eur. J. Inorg. Chem. 2020, 2020, 1635-1644. [CrossRef]

58. Yersin, H. (Ed.) Highly Efficient OLEDs Materials Based on Thermally Activated Delayed Fluorescence; Wiley-VCH: Weinheim, Germany, 2019.

59. Stephens, P.J.; Devlin, F.J.; Chabalowski, C.F.; Frisch, M.J. Relaxation dynamics in the B(1/2) and C(3/2) charge transfer states of XeF in solid Ar. J. Chem. Phys. 1994, 98, 11623-11627. [CrossRef]

60. Weigend, F. Accurate Coulomb-fitting basis sets for H to Rn. Phys. Chem. Chem. Phys. 2006, 8, 1057-1065. [CrossRef]

61. Frisch, M.J.; Trucks, G.W.; Schlegel, H.B.; Scuseria, G.; Robb, M.; Cheeseman, J.; Scalmani, G.; Barone, V.; Mennucci, B.; Petersson, G.; et al. Gaussian 09, Revision C.01; Gaussian Inc.: Wallingford, CT, USA, 2010.

62. CrysAlisPro 1.171.38.46; Rigaku Oxford Diffraction: Tokyo, Japan, 2015.

63. Sheldrick, G.M. SHELXT-Integrated space-group and crystal-structure determination. Acta Cryst. A 2015, 71, 3-8. [CrossRef]

64. Sheldrick, G.M. Crystal structure refinement with SHELXL. Acta Cryst. C 2015, 71, 3-8. [CrossRef] [PubMed] 